\title{
The Benefits of Traditional Game "Clogs" to Develop Early Childhood's Rough Motoric
}

\author{
Aneka \\ Institut Agama Islam Negeri (IAIN) Metro \\ Jl. Ki Hajar Dewantara 15 A Kota Metro \\ e-mail:anekaardi@gmail.com \\ Aufilana Rahmatika \\ Institut Agama Islam Negeri (IAIN) Metro \\ Jl. Ki Hajar Dewantara 15 A Kota Metro \\ e-mail:aufilanarahmatika9@gmail.com
}

Received: 4 May 2019; $\quad$ Revised: 25 May 2019; $\quad$ Accepted: 11 June 2019

\begin{abstract}
Traditional game is one of effective media that can be used in instructional activities for children. This is because the children can learn something while they are playing. This article discusses one of popular traditional games, called clogs (in Bahasa Indonesia: bakiak) and its benefits to improve the rough motoric of the children aged of five to six years. This game may be an alternative to improve the rough physical/motoric abilities of children aged five to six years. Rough motoric is the ability of children to engage in activities using large muscles. It is very important to be mastered by someone because it can be useful for doing daily activities. The lack of rough motoric may lead to serious problems faced by the children while playing together with friends such as running, jumping, pushing, throwing, catching, kicking, etc. These activities require and use large muscles in the body. The purpose of this clog game is to train children to work together in achieving one goal, establishing intimacy among them.
\end{abstract}

Keywords: rough motoric, Clogs, early childhood

\begin{abstract}
Abstrak
Permainan tradisional ini merupakan salah satu metode yang digunakan dalam pembelajaran karena dalam hal ini anak belajar sambil bermain, dan permainan ini merupakan permainan masyarakat yang perlu dikenalkan kepada anak usia dini yaitu permainan bakiak. Permainan ini merupakan salah satu solusi untuk meningkatkan kemampuan fisik/motorik kasar anak pada usia lima sampai enam tahun. Motorik kasar merupakan kemampuan anak beraktifitas dengan menggunakan otot-otot besar, Motorik kasar sangat penting dikuasai oleh seseorang karena dapat bermanfaat untuk melakukan aktivitas sehari-hari, bila
\end{abstract}


tidak mempunyai kemampuan gerak yang baik akan mengalami ketingalan kemampuan dari yang dimiliki orang lain misalnya tidak dapat mengikuti aktivitas bermain bersama dengan teman seperti berlari, melompat, mendorong, melempar, menangkap, menendang, dan lain sebagainya, kegiatan ini memerlukan dan menggunakan otot-otot besar pada tubuh. Tujuan permainan bakiak ini untuk melatih anak bisa bekerjasama dalam meraih satu tujuan, menjalin keakraban pada diri setiap anak.

Kata Kunci: motorik kasar, permainan bakiak, anak usia dini

\section{Introduction}

Early Childhood Education is education provided to children aged around 0-8 years. Early childhood education has been seen something very strategic in order to prepare superior and resilient future generations. This early age is the golden age in which the child will easily accept, follow, see and hear everything that is exemplified, heard and shown. Early childhood education must pay attention to all the potentials that each child has to develop optimally through fun, joyful, caring and compassionate, patient and sincere ways. ${ }^{1}$

Important potentials that need to be developed and grown in early childhood education include the potential for cognitive, religious, social-emotional, motoric and language. The five aspects of this development will rely on two tools or the main physical organs namely hearing and sight so that the growth of the five aspects is highly dependent on optimizing the use of the two main tools. ${ }^{2}$

In connection with this, Early Childhood Education (PAUD) needs to be given correctly and according to the age

\footnotetext{
${ }^{1}$ Harun and et.al.,.,Asesmen Perkembangan Anak Usia Dini (Yogyakarta: Multi Pressindo, 2009), 48.

${ }^{2}$ Harun and et.al., 53.
}

level of the child. The education provided must include all aspects of the development field so that the child's ability to develop optimally and comprehensively. One of the fields developed in early childhood education is motor development.

Rough motor development is a movement that occurs because of the coordination of large muscles. Teachers and educators can optimize rough motor skills for early childhood through a variety of interesting and fun activities. One activity that can be given to developing rough motor skills in children is through activities involving the feet, hands, and the whole body. ${ }^{3}$

According to Schmidt, motor learning is a series of (internal) learning processes related to practice or experience that lead to relatively permanent changes in the ability to respond to something. ${ }^{4}$ Motor learning can be interpreted as a learning process of movement skills and refinement of motor skills, as well as variables that support or hinder a person's ability through motor

${ }^{3}$ Elizabeth B. Hurlock, Perkembangan Anak (Alih Bahasa: Meitasari Tjandrawa) (Jakarta: Erlangga, 1978), 151.

${ }^{4}$ Richard Decaprio, Aplikasi Pembelajaran Motorik (Jogjakarta: Divapress, 2013), 17. 
skills. To help in improving rough motor skills can be done using the game.

Games are an activity that can be done by everyone, from children to adults, including those with disabilities. Games are an inseparable part of life and tend to be basic needs. Educational experts also say that children are synonymous with playing because almost all of their lives cannot be separated from playing.

According to Agus Mahendra, playing can lead to cheerfulness, agility, relaxation, and harmonization so that people tend to be passionate and can do movements without any coercion or obstacles. ${ }^{5}$ One of the examples of a game to increase rough motor skills is through the game "Clogs". For this reason, the game "Clogs" is needed as an influence to improve rough motor skills in early childhood.

Playing in a world of children, through playing they can express themselves. Hughes said that playing is a different thing from learning and working. An activity called play must have five elements in it, namely: (a). have a purpose, namely the game itself is done to get the satisfaction; (b). choose freely and on their own accord, no one orders or forces; (c). fun and can enjoy; (d). fantasize to develop imaginative power and creativity; (e). do actively and consciously. ${ }^{6}$

${ }^{5}$ Thobroni and Fairuzul Mumtaz, Mendongkrak Kecerdasan Anak Melalui Bermain Dan Permainan (Yogyakarta: Katahati, 2011), 42.

${ }^{6}$ Andang Ismail, Education Games "
The game used in this study is the method of playing clogs. According to Mulyani, traditional Indonesian games in the regions can develop aspects that are found in children. Clog requires collaboration and compactness of the players. ${ }^{7}$

Clog is a game that can improve and develop the rough motoric skills of children. Creation games can train the ability of children to read gestures, move the body, train dexterity and agility, speed, concentration and balance children in clogs, improve communication skills, cooperation and the ability to develop good strategies and train children to learn in groups using clogs. In addition, children will also be seen as active in learning motoric development and have the interest and motivation to play games with a happy heart. Clogs is one way to teach children to improve their rough motor activities; this game is typically done in groups. Clogs to foster cooperation and compactness of the players.

\section{Discussion}

\section{Rough Motoric Development of Early Childhood}

Rough motoric is the ability of children to engage in activities by using the large muscles of Yudha M. Saputra. The ability to use these large muscles for children depends on their basic motility. This ability is usually used by children to

\footnotetext{
Menjadi Cerdas Dan Ceria Dengan Permainan Edukatif" (Yogyakarta: Pilar Media, 2006), 14.

${ }^{7}$ Sri Mulyani, Permainan Tradisional Anak Indonesia (Yogyakarta: Langen Sari Publishing, 2013), 1.
} 
improve their quality of life. ${ }^{8}$

Defining that rough motoric is a body movement that uses large muscles, most or all of the body parts that are affected by the maturity of the child itself. One of the activities that can be given to develop rough motor skills in children is through activities involving the feet, hands, and the whole body (Hurlock), There are various activities that can train a child's ability to develop rough motor skills namely activity walking on-board footsteps, jumping rope, gymnastics, swimming and so on. ${ }^{9}$

Another opinion expressed by Samsudin, rough motoric is the ability of children to engage in activities using large muscles. Rough motoric is very important to be mastered by someone because it can be useful for doing daily activities, if you do not have the ability to move well you will experience the ability of others, for example not being able to participate in playing activities with friends such as running, jumping, pushing, catching, kicking, etc., this activity requires and uses large muscles in the body. ${ }^{10}$

Some of these opinions can be concluded that rough motoric is an activity that uses large muscles; most or all members of the body that can be useful in everyday life. Caughlin, stated that the rough motoric abilities of 5-6

${ }^{8}$ Yudha M. Saputra, Pembelajaran Kooperatif Untuk Meningkatkan Keterampilan Anak TK (Jakarta: Depdiknas, 2005), 117.

${ }^{9}$ Hurlock, Perkembangan Anak (Alih Bahasa: Meitasari Tjandrawa), 151.

10Samsudin, Pembelajaran Motorik Di Taman Kanak- Kanak (Jakarta: Litera, 2008), 64. years old children are: (1) standing on the other foot for 10 seconds, (2) walking on the balance board forward, (3) jumping backwards with two consecutive times participate, (4) jumping with one leg, (5) taking one or two steps, which is regular before kicking the ball, (6) throwing the ball by turning and stepping forward, (7) swinging without assistance, (8) catching it firmly, (9) jumping the knee-high rope without touching, (10) pointing to two complicated skills in mastering the ball, reflecting, bouncing or catching, and hitting the ball with a racket. ${ }^{11}$

\section{Rough Motoric Development}

Motor development is a progressive change in control and the ability to make movements that are obtained through interactions between maturity factors and training/experience during life obtained through changes/movements made. ${ }^{12}$ Motoric development is divided into two types, namely:

a. Rough motor development is a body movement that uses large or most muscles or all members of the body that are influenced by the maturity of the child itself. For example, running, tiptoeing, jumping, hanging, throwing, and catching.

b. Fine motor skills are movements that use soft muscles or a particular part of the body, which is influenced by opportunities for learning and

11Sumantri, Model Pengembangan Keterampilan Motorik Anak Usia Dini (Jakarta: Depdiknas, 2005), 103.

12Rini Hildayani, Psikologi Perkembangan Anak (Jakarta: Universitas Terbuka, 2009), 84. 
practice including rough motor and fine motor development. ${ }^{13}$

\section{Elements of Rough Motoric Ability}

The motor skills possessed by each child are different. Basically, the motor skills of each person depending on the number of movements they master. Elements of rough motor ability are identical to the elements developed in physical fitness.

The rough motor skills, according to Muthohir and Gusril, are a) Strength, the ability of a group of muscles to cause energy when contracting. Muscle strength must be possessed by children early. If the child does not have certain strengths he cannot perform play activities using physical means; b) Coordination, an ability to unite or separate in a complex work assignment, provided that the coordination movement includes perfection between the muscles and the nervous system; c) Speed, an ability based on flexibility in a certain time unit; d) Balance, an ability to maintain the body in various positions. Balance is divided into two forms, namely static balance, and dynamic balance. Static balance is the body's ability to maintain the balance of the body in a fixed position. Dynamic balance is the ability to maintain body balance when moving; e) Agility, agility is the ability of a person to change the direction and position of the body quickly and precisely when moving at one point

${ }^{13}$ As 'adi Muhammad, Panduan Praktis Stimulasi Otak Anak (Jogjakarta: DIVA Press, 2010), 19. to another. ${ }^{14}$

\section{Traditional Clogs}

Dharmamulyo argues that traditional games are games that have been played by children in a traditional area. ${ }^{15}$ Traditionally, the game is inherited from one generation to the next. Traditional games are a type of game that contains cultural values, in essence, is an ancestral heritage that must be preserved. ${ }^{16}$

Traditional games are forms of games that have existed since ancient times and passed down from generation to generation. Traditional games are cultural results that contain great benefits as community capital in maintaining their existence and cultural identity in the midst of diverse communities.

Traditional games, in general, provide fun to children and are universal so that games that appear in other areas can be played together. ${ }^{17}$ This shows that every traditional game originating from a certain area can be done by children in

${ }^{14}$ Toho Cholik Mutohir and Gusril, Perkembangan Motorik Pada Masa Anak-Anak (Jakarta: Dirjen Olahraga, Depdiknas, 2004), 34.

${ }^{15}$ Sukirman Dharmamulyo and et.al.,.,Permainan Tradisional Jawa (Yogyakarta: Kepel Press, 2008), 38.

${ }^{16}$ Andang Ismail, Education Games " Menjadi Cerdas Dan Ceria Dengan Permainan Edukatif" (Yogyakarta: Pilar Media, 2006), 105.

${ }^{17}$ Ramadhan Lubis and Khadijah, "Permainan Tradisional Sebagai Pengembangan Kecerdasan Emosi Anak," AlAthfal Jurnal Pendidikan Anak Vol. 4, no. 2 (Desember 2018):

179 , https://doi.org/http://dx.doi.org./10.14421/alathfal.42-05. 
other areas. Each region has a unique game rule.

Traditional games are a game activity that originates from a certain area that has cultural values and values for people's lives. This game is taught in stages from one generation to the next. The benefits of traditional games include: (1) children become more creative, meaning traditional games are usually made directly by the players; (2) this game as therapy for children when, namely children will release their emotions by shouting, laughing, and moving; (3) developing intellectual intelligence; (4) developing emotional intelligence; (5) develop logical intelligence; (6) developing kinesthetic intelligence; (7) develop natural intelligence; (8) developing spatial intelligence; (9) recognize the concept of space and change roles (theatrical); (10) developing musical intelligence; and (11) developing spiritual intelligence. ${ }^{18}$

The cultural values contained in traditional games are: (a) practicing an independent attitude; (b) dare to make decisions; (c) full of responsibility; (d) honest; (e) attitude controlled by opponents; (f) cooperation; (g) help and maintain each other; (h) defend group interests; (i) democratic spirit; (j) comply with regulations; (k) full calculation; (l) the accuracy of thinking and acting; $(\mathrm{m})$ not sappy; (n) brave; (o) act politely; (p) acts flexibly. ${ }^{19}$

In traditional games, there are

${ }^{18}$ Lubis and Khadijah, 180.

${ }^{19}$ Dharmamulyo and et.al.,.,Permainan Tradisional Jawa, 38. forms of games that are competing (games) and some are to fill leisure time as a form of recreation. There are games that apply specifically to boys, some of which apply specifically to girls. Then there are games that apply to both, according to the style of the game itself. There are groupings of types of games that are games that are single, one on one, there is one against the group, there are groups that oppose the group, there are groups that are opposites in groups, there are also individuals in one group who are held together in one group.

If observed from the activities carried out by children traditional games contain skills and dexterity of the feet and hands, using body strength, the sharpness of vision, the intelligence of the mind, the flexibility of gestures, imitating the natural environment, combining rhythmic movements, songs, and words according to their meanings and movements.

\section{Rough Motoric Development of Early Childhood Through Traditional Clogging Games}

The second traditional game is long clogs. This game shows things that are not much different from traditional games against marbles, namely: can develop early childhood emotional intelligence from various other aspects. These aspects include aspects of controlling emotions, such as calming down, aspects of selfmotivation such as controlling the desire to play and think positively. This long clog trains children to patiently wait their turn and wait for the readiness of one team.

Clogs are sandals that have appeared in Chinese dynasties and have developed into Asian countries so that the 
sandals contain elements of cultural value where these sandals are made from decorated pieces of wood to be beautiful. Clogs are traditional games that we often encounter when the anniversary of Indonesian independence. Traditional games that have been around for a long time, almost exist in all parts of Indonesia because of their exciting and challenging nature. ${ }^{20}$

Clogs or commonly called Terompa Galuak in Indonesia is a traditional game of children originating from West Sumatra. Clogs made of two thick wooden boards in the form of sandals that are about $125 \mathrm{~cm}$ long. On each board, there are three or four rubber straps to tie the player's legs. ${ }^{21}$ Clogging games are still popular until now, usually for 17 August events in schools or in the community.

The aim of the Clogs is to train children to work together in achieving one goal, establishing intimacy in each child. ${ }^{22}$ For some people, clogs are developed into a game of clogs with one sandal that can make four or six people then walk together or simultaneously if they are not compact the groups will surely fall. Later they stepped together to the finish line..$^{23}$

20Maria Hidayanti, Peningkatan Kemampuan Motorik Kasar Anak Melalui Permainan Bakiak, vol. Vol. 7, 1, 2013, 198.

${ }^{21}$ Sri Mulyani, 45 Permainan Tradisional

Anak Indonesia (Yogyakarta: Langensari Publishing, 2013), 9.

${ }^{22}$ Hamid Bahari, Permainan-Permainan Perangsang Karakter Positif Anak (Yogyakarta: DIVA Press, 2013), 73.

23Hidayanti, Peningkatan Kemampuan
The Benefits of Traditional Games "Clogs".... 113

This clog game requires compactness and good cooperation in the team to be able to win a race. Clogs are a traditional game that prioritizes compactness and togetherness between the participants. The players have to walk compactly to maintain a balance so as not to fall. Wood tray made of long footwear that can be used by participants between 46. How to make traditonal Clogss:

a. The board is cut to the desired size.

b. The board is smoothed using sandpaper so the surface becomes more comfortable to use.

c. Cut the rubber tire 3 pairs $( \pm 2 \mathrm{~cm})$

d. Temple rubber tires are on clog boards, using packs and hammers.

As for how to play traditional clogs games:

a. The children are divided into several groups with the number of members according to the number of steps on the clogs.

b. All groups were asked to wear clogs and stand in the start line.

c. With orders from the instructor, all groups must be quick to arrive at the finish line.

d. The group that is the fastest to the finish line is declared the winner ${ }^{24}$. If it is not synchronized, the clogs cannot be run or they will fall together because the footsteps are unbalanced or even opposite. Therefore, this game requires a high level of collaboration and care about what his friends feel. Even

Motorik Kasar Anak Melalui Permainan Bakiak, Vol. 7:198.

${ }^{24}$ Bahari, Permainan-Permainan Perangsang Karakter Positif Anak, 73-74. 
114 |Elementinly Vol.5 No.1, January-June 2019

children are also trained to enjoy sharing toys with their friends and the spirit of learning to achieve victory.

Long Clogs also train children to be able to be responding well. Clogs are carried out by team teams so that each child has the same responsibility to follow the leader's direction and the one in charge can lead well. This game also requires compactness.

\section{Conclusion}

Muscle strength must be possessed by children early. If a child does not have certain strengths, he cannot perform play activities that use physical means; b) Coordination, Coordination is the ability to unite or separate in a complex work assignment, provided that the coordination movement includes perfection between the muscles and the nervous system; c) Speed, Speed is as an ability based on flexibility in a certain time unit; d) Balance, balance is one's ability to maintain the body in various positions. Balance is divided into two forms, namely static balance and dynamic balance. Static balance is the body's ability to maintain the balance of the body in a fixed position. Dynamic balance is the ability to maintain body balance when moving; e) Agility, agility is the ability of a person to change the direction and position of the body quickly and precisely when moving at one point to another.

The long Clogs also trains compactness because long clogs are played by paddling footsteps simultaneously and matching a team. If it is not synchronized, the clogs cannot be run or they will fall together because the footsteps are unbalanced or even opposite. Therefore, this game requires a high level of collaboration and care about what his friends feel. Even children are also trained to enjoy sharing toys with their friends and the spirit of learning to achieve victory.

\section{References}

Bahari, Hamid. Permainan-Permainan Perangsang Karakter Positif Anak. Yogyakarta: DIVA Press, 2013.

Decaprio, Richard. Aplikasi Pembelajaran Motorik. Jogjakarta: Divapress, 2013.

Dharmamulyo, Sukirman, and dkk.Permainan Tradisional Jawa. Yogyakarta: Kepel Press, 2008.

Harun, and dkk. Asesmen Perkembangan Anak Usia Dini. Yogyakarta: Multi Pressindo, 2009.

Hidayanti, Maria. Peningkatan Kemampuan Motorik Kasar Anak Melalui Permainan Bakiak. Vol. Vol. 7. 1, 2013.

Hildayani, Rini. Psikologi Perkembangan Anak. Jakarta: Universitas Terbuka, 2009.

Hurlock, Elizabeth B. Perkembangan Anak (Alih Bahasa: Meitasari Tjandrawa). Jakarta: Erlangga, 1978.

Ismail, Andang. Education Games “ Menjadi Cerdas Dan Ceria Dengan Permainan Edukatif." Yogyakarta: Pilar Media, 2006.

Lubis, Ramadhan, and Khadijah."Permainan Tradisional Sebagai Pengembangan Kecerdasan Emosi Anak." Al-Athfal Jurnal Pendidikan Anak Vol. 4, no. 2 (Desember 2018). 
https://doi.org/http://dx.doi.org./

10.14421/al-athfal.42-05.

Muhammad, As 'adi.Panduan Praktis

Stimulasi Otak Anak. Jogjakarta:

DIVA Press, 2010.

Mulyani, Sri. 45 Permainan Tradisional

Anak Indonesia. Yogyakarta:

Langensari Publishing, 2013.

- - - Permainan Tradisional Anak

Indonesia. Yogyakarta: Langen Sari Publishing, 2013.

Mutohir, Toho Cholik, and Gusril.Perkembangan Motorik Pada Masa Anak-Anak. Jakarta: Dirjen

Olahraga, Depdiknas, 2004.

Samsudin.Pembelajaran Motorik Di

Taman Kanak- Kanak. Jakarta: Litera, 2008.

Saputra, Yudha M. Pembelajaran Kooperatif Untuk Meningkatkan Keterampilan Anak TK. Jakarta: Depdiknas, 2005.

Sumantri.Model Pengembangan

Keterampilan Motorik Anak Usia

Dini. Jakarta: Depdiknas, 2005.

Thobroni, and Fairuzul Mumtaz.

Mendongkrak Kecerdasan Anak Melalui Bermain Dan Permainan.

Yogyakarta: Katahati, 2011.

Yuliaarni, Diah, and

dkk."Peningkatan Kemampuan

Motorik Kasar Melalui

Permainan Bakiak Pada Anak

Usia 5-6 Tahun."Program Studi

Pendidikan Guru Pendidikan Anak

Usia Dini FKIP UNTAN, Email:

Yuliarnidiah@yahoo.co.id, n.d.

https://www.Jurnal.untan.ac.id. 